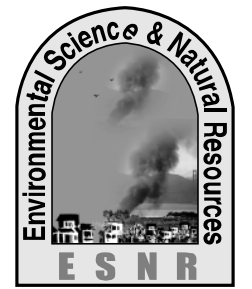

J. Environ. Sci. \& Natural Resources, 7(1): 13-19, 2014

ISSN 1999-7361

\title{
Adaptation of Char Livelihood in Flood and River Erosion Areas through Indigenous Practice: A Study on Bhuapur Riverine Area in Tangail
}

\author{
M. S. Islam ${ }^{1 *}$, S. Sultana ${ }^{1}$, Saifunnahar ${ }^{1}$ and M. A. Miah ${ }^{2}$ \\ ${ }^{1}$ Department of Environmental Science and Resource Management, \\ Mawlana Bhashani Science and Technology University, Tangail-1902, Bangladesh \\ ${ }^{2}$ Department of Environmental Science, Bangladesh Agricultural University \\ Mymensingh-2202, Bangladesh
}

\begin{abstract}
In Bangladesh, flood and river erosion is a very common event and it has been occurred since 1988 and its process is till going on. The study was conducted in two char villages of the Jamuna River in the Bhuapur upazila of Tangail districts, namely Khanurbari and Shushua char from July to December 2011. The empirical data and findings were procured by the application of social survey, focus group discussion and field observation. The study explored the people's indigenous survival techniques and assessed variation in people's ability to adopt with floods and river erosion in those char villages. The result of the study showed that the people in char land with high flood proneness and low socio-economic circumstances were more likely to fail to adopt with impacts compared to people in areas with high and sudden flooding. The char people use their indigenous knowledge to adapt through this diverse situation. The study explores a negative fact that without any organizational support, the people of char have to formulate and undertake various adaptation techniques in their own way. Finally, the study recommended some suggestions for the policy planners and implementers for the future development of char areas in Bangladesh. It emphasizes the importance of the government and the non-governmental organizations to take their own responsibilities in the devastating situation of the flood and riverbank erosion.
\end{abstract}

Key words: Char land, Erosion, Jamuna River

\section{Introduction}

Bangladesh is the largest deltaic plain in the world. It is traversed by the Ganges, Brahmaputra, and the Meghna river system and their tributaries and distributaries. The total area of the country is $147570 \mathrm{~km}^{2} ; 6.7 \%$ of which consist of rivers and island water bodies. Some $88 \%$ of the country's total area belongs to the GBM region (Ahmed et al, 2001). Bangladesh is one of the least developed countries of the world. The population is 140.79 million with growing rate of 1.23 year (UNDP, 2011) and $76.61 \%$ of the population lives in the rural areas. Bangladesh is also a disaster prone. It is also a developing country discharges with numerous problems of over population, poverty, complex socio-economic structure, frequent disasters, low level industrial base, and resource constrains, lack of appropriate infrastructural and institutional facilities, dearth of trained manpower etc country (Hossain and Ferdousi, 2004).

Bangladesh is one of the most disaster-prone countries in the world. The state of Bangladesh is possibly the single largest concentration of people in a highly disaster-prone environment, with most of its 140.23 million people at significant risk to more than one form of natural hazard. Various natural calamities affected at various region of Bangladesh. Flood is one of them. Flood is the most frequent and considered to be the main hazard of Bangladesh. About $50 \%$ of land area lies between $0-50 \mathrm{~cm}$ above the main sea level. Major rivers flowing in the country are in old stage and due to heavy rainfall in the country and in the catchments areas, high volume of floodwater flow during the monsoon period (Benson and clay, 2002).

Riverbank erosion in the Jamuna River is one of the major problems in Bangladesh. Every year thousands of people become homeless and they lose their homestead and croplands. Mosques, schools, hospitals and other infrastructures are damaged due to erosion into the mighty Jamuna River. The erosion affected people migrate to cites or nearest town and they live in the urban slum areas (CEGIS, 2009). A number of erosion affected people take shelter on Brahmaputra Right Embankment (BRE) or live on the permanent or semi-permanent sandbar (char). The livelihood of char people is described by Schumuck-Widmann (2001) and Sarker et al. (2003). Population displacement due to flood and river erosion is considered as one of the main contributors to landlessness and impoverishment of rural population. About 10,000 hectares of land per year is eroded by river in Bangladesh (NWMP, 2001).

Besides, unique natural setting of Bangladesh and the characteristics of tropical monsoon climate are greatly responsible for flood hazards in the country (Elahi, 2001). "Charland" is the Bengali term, its English meaning is "Riverine Island". Mid-channel Island that periodically emerges from the river bed as a result of accretion. The Riverine Islands of Bangladesh can be divided into five sub areas such as the Jamuna, the Ganges, the Padma, the upper Meghna and the lower Meghna River. The old Brahmaputra and Tista also constitute some riverine 
island area again riverine islands are areas of new land formed through the continual process of erosion and deposition in the major rivers and coastal areas. The whole of the riverine island is unstable and prone to annual flooding (Kabir, 2006).

The char dwellers are some of the poorest and most vulnerable people particularly those who live on the island/attached river chars although people living on the unprotected riverbanks experience similar difficulties. Riverbank erosion is a perennial problem in Bangladesh, causing loss of lands and livelihood along major rivers. Riverbank erosion is a major environmental and social problem in Bangladesh, where $30-40 \%$ of the population lives close to river banks. Riverbank erosion is the gradual (series of small changes) removal of rock (hard and solid materials) materials from the riverbanks and bed. (Roy et al., 2007).

Char land areas irrespective of their geographic attachment to the mainland and distance from the growth centers are particularly vulnerable to flood, drought and river erosion (ISPAN, 2003). Char people use their indigenous knowledge to adapt through this diverse situation. So it is important to improve and indicate the indigenous knowledge to adapt with the char environment. The findings of our study shows that how the char people adapt themselves with the erosion and flood. Thus the study will focuses to find out the causes addressing the adaptation techniques of the char people in different sector of their livelihood in char. These findings can help the government and the other organization to take proper steps for improving the livelihood of the char people (Paul and Routray, 2010).

Due to flood and river erosion, terrestrial and fresh water biodiversity are lost. These are indirectly effects on environment. Flood has not only demerits but also has merits. Flood carries silt which falls on the fields and makes the land fertile. This is natural manure which saves artificial fertilizers. As a result many kinds of crops grow or plenty. Flood washes away the dirty things. The objectives of the study were as follows: i) to identify the indigenous practices of char land inhabitants to adapt with flood and river erosion, ii) to identify the impact of flood and river erosion on char people, iii) to determine the nature of the flood and river erosion in char land.

\section{Materials and Method \\ Study area \\ The study was conducted in two char villages under Bhuapur upazila under Tangail district which falls in flood prone area of the country. Bhuapur upazila}

was primarily selected as a suitable area for the study because this upazila is situated near the bank of the Jamuna which comes under regular flood and char peoples are highly vulnerable to river erosion and flood damage. Two char village namely Shushua char and Khanurbari char were selected as specific study location. The selection was made on the basis of suggestions made by the Union Parishad Office (UPO), Bangladesh Water Development Board (BWDB), Union Parishad Members and Officials of Bhuapur upazila. The two char villages are situated in flood prone areas which are naturally low land. All most every year flood occurs in these villages and causes human sufferings and damage to crop, livestock, fisheries and other resources.

\section{Data collection}

Different kinds of data like the area of the studied area, population of the area, cultivable land of the area, past data on flooding and the river erosion were collected from the Union Parishad Office, BWDB etc. The data about the settlement pattern, land used, population, land area collected as secondary data from BBS, BWDB, and Settlement Office etc. To find out adaptation practice with flood and river erosion of char land people, a field survey as questionnaire survey, Key Informant Interview and open discussion were conducted randomly with the authorities of Union Parishad and local people.

\section{Data analysis}

Data were collected during the period of July to December, 2012. The statistical measures such as number and percent distribution were used for describing the variables of the study. Both the Statistical Package for Social Science (SPSS version 14.0) and Microsoft Office Excel 2003 were employed to analyze the questionnaire data.

\section{Results and Discussion}

People in both villages develop their own adapting techniques to guard against the flooding. Characteristics of flood are very important as the external determinant of the coping technique. These characteristics include the height of flood water and the frequency and duration of flooding, influence people's adoption of coping techniques. A longer period of stagnating flooding has more severe consequences than flood water height. If Flood water remains stagnant for a long time in a locality, the level of account of total damage rises and the situation of the people worse again and again. 
Table 1. Height of flood water and duration of flood in study area

\begin{tabular}{ccc}
\hline Chars & Height of flood water & Duration of flood \\
\hline Khanurbari char & $2-3$ feet's & 3 weeks \\
& $3-5$ feet's & 2 weeks \\
& $>5$ feet's & $4-5$ days \\
\hline \multirow{2}{*}{ Shushua char } & $1-2$ feet's & 4 weeks \\
& $2-3$ feet's & 2 weeks \\
& 4 feet's & 5 days \\
\hline
\end{tabular}

Source: UNO Office, Bhuapur upazila.

According to the survey, the majority of respondent in two char village used groundwater from shallow hand tube-wells and access to clear drinking water was high. In figure, it was clear that $67 \%$ of the total respondents in Shushua char used tube well water as the source of their drinking water, which was smaller than that of the national rural rate $96.42 \%$ (BBS, 2008), whereas 58\% respondents in Khanurbari char were used tube-well water for drinking purpose.

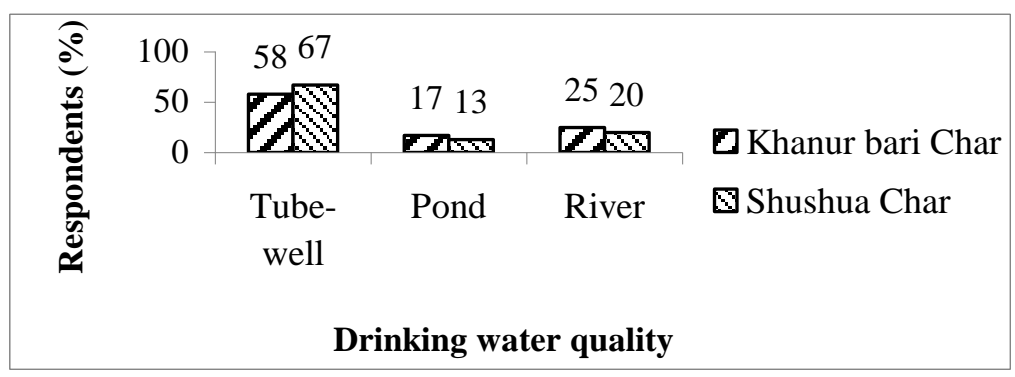

Fig. 1. Sources of drinking water in two char village

Peoples are tried to purify water during and after flood but when they are failed to do this then they drink unsafe water. It was not possible to boil water frequently as traditional fuel resources (such as bamboo, cow dung cakes and fuel wood) become wet during flood. The most common methods of water purification in villages are boiling of water.
But most of the respondents in two char villages use water without purification. About 25\% respondents in Khanurbari char purifying water through water boiling system., whereas in Shushua char $35 \%$ respondents purifying water through water boiling system (Fig. 2).

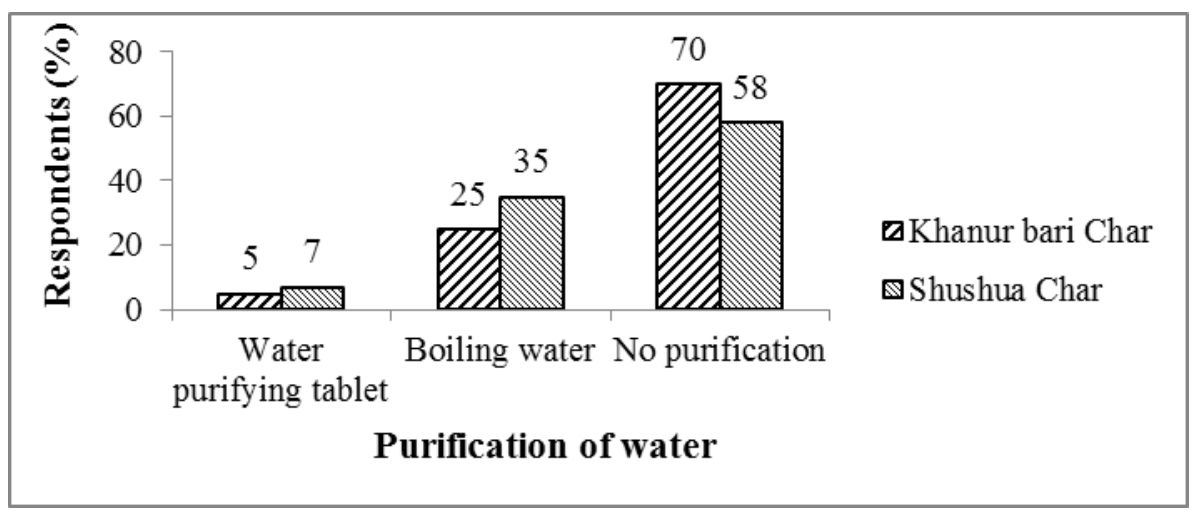

Fig. 2. Water purification during flood in selected sampling area

Table 2 revealed that majority $(31 \%)$ of the respondents in Khanurbari and Shushua char used leaves and woods as fuel for their cooking purpose. No respondents used kerosene due to their poverty and low income but nationally $2.32 \%$ rural population used kerosene. They used cow dung combined with wood and leaves about $17 \%$.
Twelve percent $(12 \%)$ of the respondents used timber or woods as their source of fuel for cooking which is smaller than that of the national rural level $57.63 \%$ (BBS, 2009). In the study area $8 \%$ of the respondents used wood and cow dung as their fuel source and $9 \%$ of the respondents used only leaves. 
Table 2. Distribution of the respondents according to their source of fuel for cooking

\begin{tabular}{|c|c|c|}
\hline Source of fuel & Khanrbari char & Shushua char \\
\hline Wood or timber & 12 & 12 \\
\hline Leaves & 9 & 9 \\
\hline Cow dung & 0 & 0 \\
\hline Wood and cow dung & 8 & 8 \\
\hline Leaves and cow dung & 23 & 23 \\
\hline Leaves and Wood & 31 & 31 \\
\hline Wood, leaves and cow dung & 17 & 17 \\
\hline Kerosene & 0 & 0 \\
\hline Total & 100 & 100 \\
\hline
\end{tabular}

Sanitation in the study area tends to be unhygienic with existing latrines poorly maintained. It is found that $52 \%$ respondents in Khanurbari char and $55 \%$ respondents in Shushua char use kacha latrine. Only $25 \%$ respondents practiced open defecation in Khanurbari char which was larger than that of the national rural rate $39.72 \%$ where $15 \%$ respondents in Shushua char use open place for sanitation (BBS, 2009). Their sanitation situation is alarming in regard to public health in the study villages. During the dry season, latrines work well as the sandy soils in the study area provide good drainage. But sanitation becomes extremely difficult during peak floods when water covers all the homestead land.

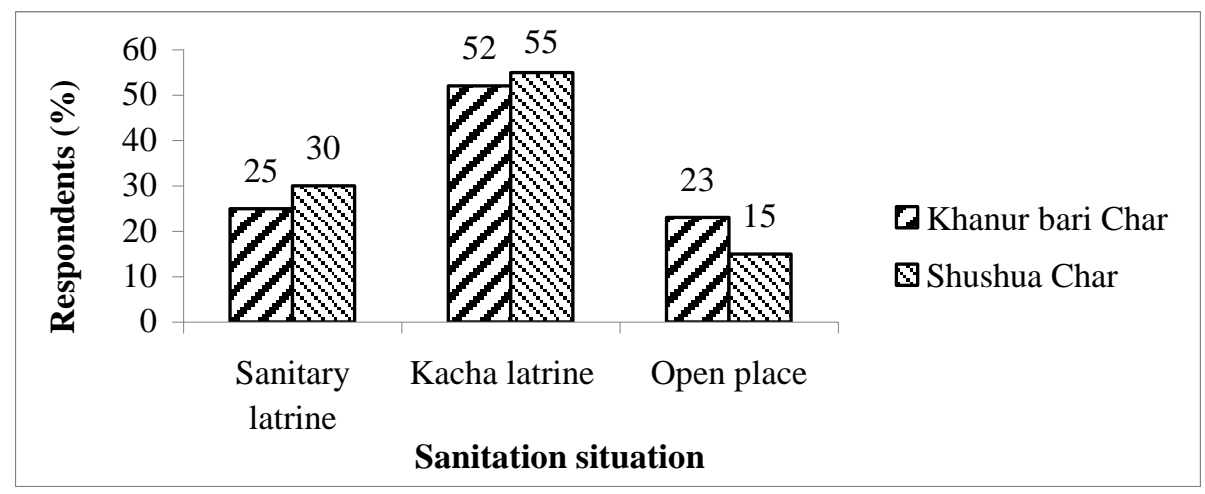

Fig. 3. Sanitation situation in two char villages

River erosion seriously affects the livelihood of the riparian population. Due to riverbank erosion, many farmers become poor overnight. They lose homestead, houses, cultivable land, trees and other properties. Different types of materials are used to protect river bank erosion. In figure, $50 \%$ respondents in Khanurbari char used piled sand bag to river erosion where as in Shushua char the total respondents is $64 \%$. In Khanurbari char, 35 and $15 \%$ of the respondents use zeo soil bag and brick piece to protect flood and river erosion where as in Shushua char the percentage is 25 and $11 \%$.

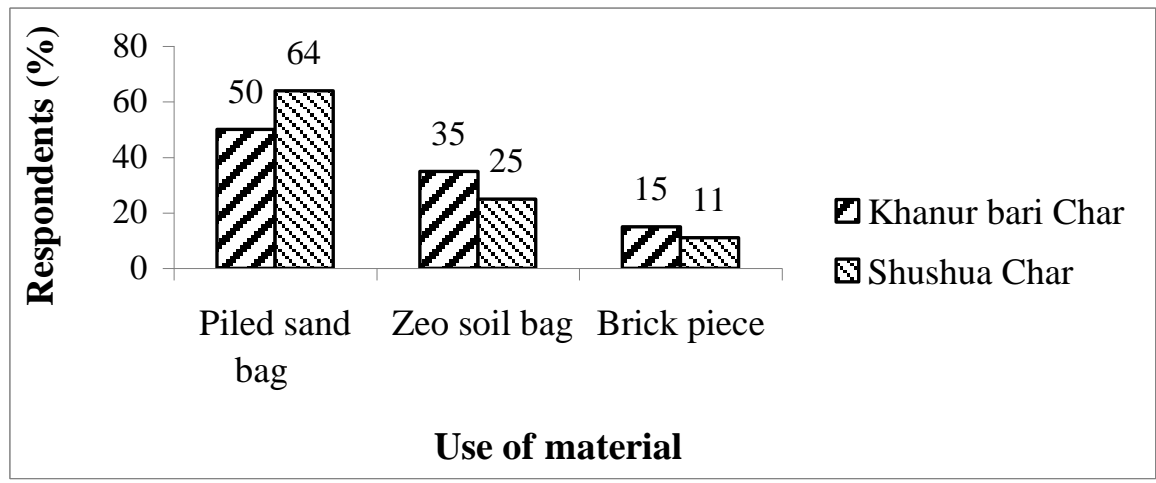

Fig. 4. Material use to protect river erosion in two char villages

Riverbank erosion has a great impact on agriculture. The impact on agriculture as a result of erosion is shown in Table 3. On an average, 60 and $67 \%$ of the respondents in Khanurbari and Shushua 
char opined that the cropping pattern is changed as a result of bank erosion. It also affects the crop diversity. Rice growing fertile cultivable land is becoming unsuitable for rice cultivation due to sand deposition. The fertility of the land is reduced as a result of erosion and sand deposition, the yield of the land is declined. The people produce maize, dal, groundnut, etc on the newly formed charland. It is evident that the crop diversity is changing. Not all the emerged lands are suitable for crop production. Therefore, the crop intensity is also changing. About $65 \%$ of the respondents in Khanurbari char said that the crop is severely damaged during erosion where as in Shushua char the total respondents is $76 \%$.

Table 3. Impact on agriculture during flood and river erosion in two char villages

\begin{tabular}{lcc}
\hline \multicolumn{1}{c}{ Item } & Khanurbari char (\%) & Shushua char $(\%)$ \\
\hline Impact on agriculture & 73 & 84 \\
Changed cropping pattern & 60 & 67 \\
Decline of production & 65 & 72 \\
Change in crop diversity & 50 & 64 \\
Impact on cropping intensity & 75 & 52 \\
Damage of crop & 65 & 76 \\
\hline
\end{tabular}

The relief and benefit are received by the victims of erosion presented in Table 4. It is found from this Table that only one fifth of the respondents received relief during the emergency situation. At present some NGOs are working on the char. They are helping the charland people in raising their homestead to be safe from high flood. Erosion and deposition are the synchronized process. Therefore, erosion causes at one place and deposition or char formation occurs at another places. They get their original land through formation of a new char. Thus, sometimes they indirectly are benefited through bank erosion.

Table 4. Relief and benefit of erosion victims in two char villages

\begin{tabular}{lcc}
\hline \multicolumn{1}{c}{ Item } & Khanurbari char (\%) & Shushua char (\%) \\
\hline Received relief service & 20 & 16 \\
Shelter on embankment & 15 & 17 \\
Development services from NGOs & 10 & - \\
Land from accreted char & 5 & 8 \\
Aid in raising homestead & - & - \\
\hline
\end{tabular}

It is evident that (Table 5) temporary migration is prevalent in both of the study areas. People in both of the study areas migrate in temporal scale rather than permanent one. They migrate to distant places most often in search of jobs. Respondents identified that because of the lack of money, they cannot migrate with their family to a place where erosion does not take place. Therefore, they relocate their homestead in a nearby area immediately after the disaster strikes and the people who are able to do laborious job, migrate to distant places in order to cope up with losses incurred from riverbank erosion. However, they have to migrate in different districts of Bangladesh to get jobs to perform their livelihood. Contrary to this, the people of Khanur bari and Shushua char move to nearby place first (in case of char land they migrate to another char and in other cases, towards the Upazila headquarters) and then to Sirajganj and Dhaka (Table 5). Tendency towards migration to long distance is also prevalent here as they frequently move to Tangail and Bogra.

Table 5. Migration pattern observed in two char village

\begin{tabular}{cccccc}
\hline Age group & \multicolumn{5}{c}{ Migration place } \\
\cline { 2 - 6 } & Bogra (\%) & Dhaka (\%) & Mymensingh (\%) & Sirajganj (\%) & Tangail (\%) \\
\hline $20-25$ & 11 & 35 & - & 30 & 5 \\
$26-30$ & 9 & 12 & - & 22 & 9 \\
$31-35$ & 4 & 9 & 9 & 11 & 2 \\
$36-40$ & 4 & 2 & 12 & - & - \\
$41-45$ & - & - & - & 5 & - \\
$46-50$ & - & - & - & 13 & 10 \\
$50+$ & - & - & - & - & - \\
\hline
\end{tabular}


The study reveals that people between 20-35 years of age move to different districts of Bangladesh like Bogra, Sirajganj, Dhaka, Tangail etc. while age groups of 31-35 and 26- 30 were found as the highest long distant migrants in Dhaka and Sirajganj respectively. Those who are more than 35 years of age, try to maintain their livelihood by migrating to their own district level living through different occupation like rickshaw/ van puller, day laborer etc. Such migration pattern makes them return to their locality after minimum of three days to maximum of 15 days staying. It was also observed that people who are more than 50 years, tried to stay in their household as they are less capable to do hard work.
River bank erosion is one of the most important natural hazards, which causes widespread damage to man and its habit. The char people experiences both normal and severe bank erosion, a hazardous phenomenon quite common in the riverine environment. Riverbank erosion is so intense and devastating that its impacts on human habitation, more especially the extent, nature the scale of devastating in the erosion risk area need proper evaluation. In this study, a detailed look is taken at the inhabitants of Bhuapur upazila based upon a questionnaire survey so that the general characteristics of the affected population, their perception regarding erosion hazards damages and related facts are meaningfully understood.

Table 4. Erosion attack and distance of homestead from riverbank during last displacement

\begin{tabular}{|c|c|c|c|c|c|c|}
\hline \multirow[t]{2}{*}{ Events } & \multicolumn{2}{|c|}{$\begin{array}{c}\text { Khanurbari (HH) } \\
\mathrm{N}=100\end{array}$} & \multicolumn{2}{|c|}{$\begin{array}{c}\text { Shushua char (HH) } \\
\qquad \mathrm{N}=100\end{array}$} & \multicolumn{2}{|c|}{$\begin{array}{l}\text { Both char villages } \\
(\mathrm{HH}) \mathrm{N}=200\end{array}$} \\
\hline & $\mathrm{N}$ & $\%$ & $\mathrm{~N}$ & $\%$ & $\mathrm{~N}$ & $\%$ \\
\hline \multicolumn{7}{|c|}{ Nature of erosion attack } \\
\hline Very quick & 21 & 21 & 92 & 92 & 113 & 56.5 \\
\hline Quick & 63 & 63 & 8 & 8 & 71 & 35.5 \\
\hline Slow & 15 & 15 & 0 & 0 & 15 & 7.5 \\
\hline Very slow & 1 & 1 & 0 & 0 & 1 & 0.5 \\
\hline \multicolumn{7}{|l|}{ Distance (M) } \\
\hline $1-500 \mathrm{~m}$ & 37 & 37 & 38 & 38 & 75 & 37.5 \\
\hline $600-1000 \mathrm{~m}$ & 20 & 20 & 44 & 44 & 64 & 32.0 \\
\hline $1000-1500 \mathrm{~m}$ & 19 & 19 & 16 & 16 & 35 & 17.5 \\
\hline $1500-2000 \mathrm{~m}$ & 24 & 24 & 12 & 12 & 26 & 13.0 \\
\hline
\end{tabular}

Note: $\mathrm{HH}=$ Household head

\section{Conclusions}

The impact of flood and river erosion on the socioeconomic condition of the displaced population was multilateral. From the above discussion it is clear that the erosion has a great impact on the livelihoods of riparian population, agriculture, and environment. Different types of vulnerabilities are generated as a consequence of erosion. Family relation and social bondage have been broken down, and the social status has been degraded. Finally, this study confirms that although flooding and river erosion in Bangladesh always generates socioeconomic and health related hazards and environmental and infrastructural damage. Long-term policies and strategies should be taken to cope up with the bank erosion taking into account the social and institutional adjustment measures. Land relocation assurance is one of the appropriate strategies to cope up with such disaster. In addition, a floodplain zoning is essential to lessen the vulnerability of riverbank erosion. Furthermore, measures should be taken in different level to minimize the loss: awareness program should be taken for char livelihood about flood and river erosion, sustainable embankment construction and its maintenance, immediate relief program should have to be undertaken by the government and other non-governmental organization during the period of flood and erosion, government should take initiatives to provide the alternative employment opportunities for the affected people, and training on disaster preparedness involving local institution/ local government.

\section{Acknowledgements}

Sincere gratitude goes to all the authorities related to our study, including Arjuna and Gobindashi Union Parishad and Settlement Office, Bhuapur, Tangail; Bangladesh Water Development Board (BWDB), Tangail; all the expert in the relevant field and general people who are our main source of information's living in the char. 


\section{References}

Ahamed, R.U. 2001. Impact of Bank Erosion of the Jamuna River on selected towns in the Northern Region of Bangladesh. PhD Report, Department of Geography and Environment, Jahangirnagar University, Savar, Dhaka.

BBS (Bangladesh Bureau of Statistics). 2008. Statistical Year Book of Bangladesh. Bangladesh Bureau of Statistics, Statistical Division, Ministry of Planning. Government of the People's Republic of Bangladesh.

BBS (Bangladesh Bureau of Statistics). 2009. Statistical Year Book of Bangladesh. Bangladesh Bureau of Statistics, Statistical Division, Ministry of Planning. Government of the People's Republic of Bangladesh.

Benson, C. and Clay, E. 2002. Bangladesh: Disaster and Public Finance. Disaster Risk Management working paper series no. 6. The World Bank, Washington D. C.

CEGIS (Center for Environmental and Geographic Information Services). 2009. Prediction of River Bank Erosion along the Jamuna, the Ganges and the Padma Rivers.

Elahi, K.M. 2001. Population Redistribution and Mobility Transition in south Asia. Dhaka: Center for Population Studies. Dept. Geography, Jahangirnagar University, Savar, Bangladesh.

Hossain, M.M. and Ferdousi, S. 2004. Assessment for role of GIS Based Natural Disaster Database in Environmental Management and Planning activity in Bangladesh. Environmental Informatics Archives, 2: 855-863.
ISPAN (Irrigation Support Project for Asia and Near East). 2003. Char Land Study Overview: Summary Report (Draft). Flood Plain Coordination Organization, Ministry of Irrigation, Water Development and Flood Control, Dhaka.

Kabir, R.D. 2006. The state of char education in Bangladesh: focus on selected chars of Gaibandha district. Asian Affairs, 28(3): 524.

National Water Management Plan. 2001. Ministry of Water Resources.

Paul, S.K. and Routray, J.K. 2010. Flood proneness and coping strategies: the experiences of two villages in Bangladesh. Disasters, 34(2): 489-508.

Roy, M.K.; Syed, S.U.I. and Azim, A. 2007. Settlement of a Char land Community: A Study on Social Crisis and Coping Pattern. A paper presented at the seminar organized Bangladesh Economic Association, Dhaka, Bangladesh.

Sarker, M.H.; Haque, I.;. Alam, M. and Koudstaal, R. 2003. Rivers, chars and char dwellers of Bangladesh. Int. J. River Basin Management, 1(1): 61-80.

Schmuck-Widmann, H. 2001. Facing the Jamuna River, Indigenous and Engineering Knowledge in Bangladesh, Bangladesh Resource Centre for Indigenous Knowledge,

UNDP (United Nations Development Program). 2011. United Nations Development Program Report. Professor's Current Affairs. September. Dhaka: Professor's Publication. 